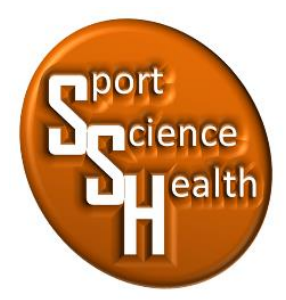

ISSN 2715-3886

\title{
Pengaruh Pemberian Sport Massage Terhadap Tekanan Darah Sistole, Diastole dan Denyut Nadi Pada Pemain Bola Voli
}

\author{
Yulius Agung Saputro ${ }^{1 *}$ \\ ${ }^{1}$ Program Studi IImu Keolahragaan, Fakultas Keguruan dan IImu Pendidikan, Universitas Mercu Buana \\ Yogyakarta, Jl. Raya Wates-Jogjakarta, Karanglo, Argomulyo, Kec. Sedayu, Bantul, Daerah Istimewa \\ Yogyakarta 55752, Indonesia \\ *Penulis koresponden: ajuliussaputro@gmail.com, 085786760577
}

Artikel diterima: 29 Juli 2020; direvisi: 19 Agustus 2020; disetujui: 23 Agustus 2020

\begin{abstract}
The purpose of this study was to determine whether or not the effect of giving this type of massage on systolic blood pressure, diastole and pulse on the volleyball player Mentaos Klaten. This study is a True Experiment Design study, a post-test pre-test group control design. The population in this study was the Mentaos Klaten volleyball players of 20 people. The data in this study were obtained by using tests and measurements to be given treatment (treatment) running 2400 meters, then after being given treatment again measured with a stetoscope and blood pressure meter. Blood pressure is measured using a Sphgymomanometer. Research data analysis techniques using the T-test with a significance level of $5 \%$. The results showed that there was a significant influence on the pulse and blood pressure through the provision of sports massages, both blood pressure systole, diastole, and pulse. The conclusion of this study is that sports massage can restore blood pressure and pulse as before.
\end{abstract}

Keyword: sport massage, sitole, diastole, pulse rate

\begin{abstract}
Abstrak: Tujuan dari penelitian ini adalah untuk mengetahui ada tidaknya pengaruh pemberian jenis massage terhadap tekanan darah sistole, diastole dan denyut nadi pada pemain bola voli Mentaos Klaten. Penelitian ini merupakan penelitian True Eksperiment Design, rancangan kontrol grup pre-test post-test. Populasi dalam penelitian ini adalah pemain bola voli Mentaos Klaten sebanyak 20 orang. Data dalam penelitian diperoleh dengan menggunakan tes dan pengukuran dengan diberikan perlakuan (treatment) lari 2400 meter, kemudian selelah diberi perlakuan diukur kembali dengan stetoscope dan tensi meter. Tekanan darah diukur dengan menggunakan Sphgymomanometer. Teknik analisis data penelitian menggunakan uji -T dengan taraf signifikasi $5 \%$. Hasil penelitian menunjukan bahwa ada pengaruh yang signifikan pada denyut nadi dan tekanan darah melalui pemberian sport massage, baik tekanan darah sistole, diastole, maupun denyut nadi. Kesimpulan penelitian ini adalah sport massage dapat mengembalikan tekanan darah dan denyut nadi seperti semula.
\end{abstract}

Kata kunci: sport massage, sitole, diastole, denyut nadi

\section{PENDAHULUAN}

Otot dapat berkontraksi dan berelaksasi karena tersedianya energi dari sistem energi. Melalui kontraksi otot, tubuh manusia mampu melakukan kerja seperti mesin. Dengan kata lain, otot merupakan mesin pengubah energi kimia menjadi energi mekanik, yang terwujud dalam suatu kerja atau aktivitas fisik. Otot rangka/skelet 
tersusun oleh kumpulan serabut (sel) otot bergaris (muscle fiber/skeletal myocyte), mempunyai banyak inti yang terletak di tepi. Dinding atau membran sel disebut sarkolemma mempunyai kemampuan menghantarkan impuls (potensial aksi) kesemua arah temasuk melanjutkan penghantaran sepanjang dinding tubulus transversalis (transvere tubule/Ttub). Sitoplasma serabut otot atau sarkoplasma mengandung struktur kontraktil (suatu cytoskeleton) yang berperanan terhadap fungsi utama otot rangka yaitu fungsi kontraksi. Kelelahan otot membatasi kinerja otot. Kelelahan otot dapat bersifat lokal maupun menyeluruh. Dapat menyertai olahraga endurans maupun olahraga yang berintensitas tinggi yang berlangsung singkat (Raya, Yunus, \& Adi, 2019).

Memijat adalah suatu seni gerak tangan yang bertujuan untuk mendapatkan kesenangan dan memelihara kesehatan jasmani (Boguszewski, Szkoda, Adamczyk, \& Białoszewski, 2014). Memijat yang menggunakan gerakan tangan secara mekanis akan menimbulkan rasa tenang dan nyaman bagi penerimanya (Davis, Alabed, \& Chico, 2020). Bagi olahragawan maupun atlet yang berprestasi pijatan akan dapat membatu memulihkan kondisi fisik ketika mengalami kelelahan (Dawson, Dawson, Thomas, \& Tiidus, 2011). Pada intinya memijat diperlukan bagi olahragawan untuk menjaga kebugaran dan kesehatan (Kargarfard et al., 2016).

Salah satu jenis massage yang dikenal secara luas dalam olahraga adalah sport massage (Schilz \& Leach, 2020). Sport massage dirancang untuk melancarkan sirkulasi peredaran darah (Paoli et al., 2013), merelaksasikan otot setelah beraktivitas olahraga dan pengolahan sisa metabolisme (Peterson et al., 2015). Dengan rancancangan tersebut Sport massage sangat tepat apabila digunakan sebagai sarana pemulihan tubuh setelah aktivitas olahraga (Fallis, 2013). Sport massage menggunakan jantung sebagai pusat peredaran darah (IImi, 2018). Tujuannya adalah mempercepat aliran cairan lymphe dan darah veneus atau darah venosa (Farber \& Wieland, 2016). Gerakan kontraksi otot jantung mendorong darah untuk beredar ke seluruh tubuh dan kemudian kembali ke jantung, terutama gerak menghisap atau diastole (Trampas, Mpeneka, Malliou, Godolias, \& Vlachakis, 2015).

Permainan bola voli diciptakan oleh William G. Morgan pada tahun 1895 (Kristriawan \& Sukadiyanto, 2016). Awalnya nama permainan ini disebut "Minonette" yang hampir serupa dengan permainan badminton (Daulay \& Daulay, 2018). Kemudian nama permainan ini dirubah menjadi "Volley-Ball" yang memiliki arti kurang lebih memvolley bola secara berganti-gantian.

Bola voli merupakan sebuah permainan beregu termasuk permainan menggunakan bola besar (La'l \& Haluti, 2018). Permainan bola voli dimainkan oleh dua regu atau tim, tiap regu terdiri dari 6 pemain (Samsudin \& Rahman, 2016). Permainan ini membutuhkan koordinasi dan kerja sama tim (Pranopik, 2017). Di Indonesia mulai mengenal permainan ini sejak tahun 1928, yakni melalui serdadu dari Belanda. Kemudian tidak lama, berdirilah berbagai klub bola voli di tanah air Indonesia. Awalnya pada tanggal 22 Januari 1955, di Jakarta berdirilah PBVSI (Persatuan Bola Voli Seluruh Indonesia) yakni sebagai induk olahraga bola voli di Indonesia (goleman, daniel; boyatzis, Richard; Mckee \& Perdana, 2018).

Pada aktivitasnya pemain bola voli Mentaos setelah melakukan latihan drill fisik membutuhkan waktu yang cukup lama untuk mengembalikan kelelahan tubuhnya. Hal ini dikarenakan latihan fisik dilakukan dengan intensitas tinggi. Pemain setelah melakukan latihan fisik yang berlanjut ke jam berikutnya mengalami kelelahan yang tinggi saat melakukan aktivitas lainya, sehingga peneliti mencoba mengamati kondisi awal pemain bola voli Mentaos tersebut dengan melihat tekanan darah dan denyut nadi, ternyata hasilnya masih belum menurunkan tekanan darah dan denyut nadi setelah selesai mengikuti latihan fisik. Maka peneliti ingin melakukan pengamatan yang lebih dalam lagi dengan mengadakan penelitian kepada pemain bola voli Mentaos yang berjudul pengaruh pemberian jenis massage terhadap tekanan darah sistole, diastole dan denyut nadi pada pemain bola voli Mentaos Klaten.

Hubungan Sport massage sangat tepat apabila digunakan sebagai sarana pemulihan otot setelah beraktivitas, apalagi untuk sekelas klub olahraga. Tentunya sangat banyak kejadian-kejadian yang menyebabkan otot atlit kelelahan lewat latihan yang continue, seperti yang dialami oleh pemain bola voli Mentaos Klaten. Untuk itu peneliti ingin membuktikan pernyataan tersebut maka peneliti ingin melakukan pengamatan yang lebih dalam lagi dengan mengadakan penelitian kepada pemain bola voli Mentaos yang berjudul pengaruh pemberian jenis massage terhadap tekanan darah sistole, diastole dan denyut nadi pada pemain bola voli Mentaos Klaten. 


\section{METODE}

Penelitian ini adalah penelitian True Exsperimental Design dengan desain dua kelompok dengan control group pretest-posttest design. Desain penelitian dua kelompok dengan control group pretest-posttest design (DiStefano, Distefano, Frank, Clark, \& Padua, 2013), dapat digambarkan sebagai berikut:

\begin{tabular}{cccc}
$E$ & $O_{1}$ & $X$ & $O_{2}$ \\
\hline$E$ & $O 3$ & $X$ & $O_{4}$
\end{tabular}

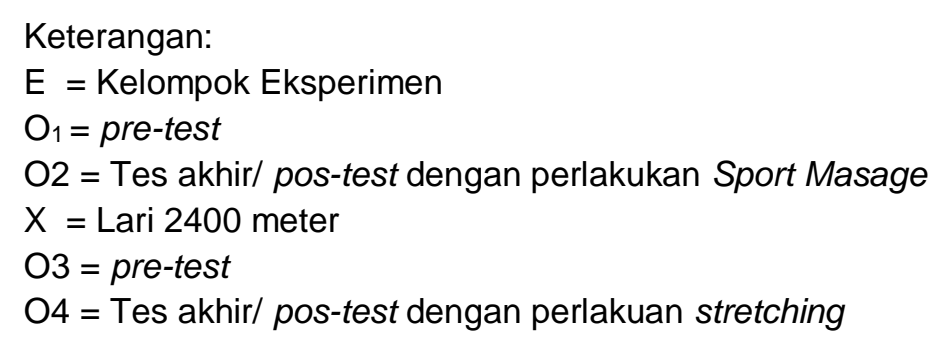

\section{Deskripsi Lokasi dan Subjek Penelitian}

Penelitian dilaksanakan di lapangan Lapangan Bola Voli Mentaos Klaten. Pengambilan data dilakukan pada 12 januari 2020 Pukul 14.00 WIB. Sampel penelitian ini adalah Pemain Bola Voli Mentaos sebanyak 20 orang. Keseluruhan sampel yang digunakan berada pada kondisi yang sehat.

Sebelum dilakukan eksperimen, yaitu dengan pemberian sport massage pada subjek penelitian, maka dilakukan pembagian menjadi 2 kelompok, yaitu kelompok eksperimen dan kontrol. Pembagian dua kelompok tersebut menggunakan teknik macth pairing dengan model ABBA. Dengan model tersebut, maka diperoleh dua kelompok yang memiliki rerata tekanan darah dan denyut nadi yang seimbang.

\section{Sampel Penelitian}

Sampel dalam penelitian ini dibagi menjadi dua kelompok, yaitu kelompok A dan B. Kelompok A diberikan tes awal, yaitu dicek denyut nadi per 60 detik dan dicek tekanan darah baik sistole maupun diastole dengan menggunakan alat Sphgymomanometer. Setelah itu, diberikan perlakuan (treatment) lari 2400 meter, dan setelah selesai lari kelompok eksperimen diberikan perlakuan sport massage seluruh tubuh, kemudian diadakan tes akhir untuk melihat kembali denyut nadi per 60 detik. Untuk kelompok eksperimen setelah melakukan lari lari 2400 meter, perlakuan sport massage waktunya 45 menit. Begitu juga pada kelompok B, hanya saja tidak dilakukan pemberian sport massage, namun tetap melakuan lari lari 2400 meter untuk menentukan tekanan darah dan denyut nadi.

\section{Pengambilan Data Penelitian}

Data dalam penelitian adalah data yang diperoleh dengan menggunakan tes dan pengukuran dari populasi dengan cara menghitung denyut nadi dan tekanan darah sebelum perlakuan baik aktivitas lari ataupun non aktivitas, kemudian selelah diberi perlakuan diukur kembali dengan stetoscope dan tensi meter. Tekanan darah diperoleh melalui pengukuran sistole dan diastole. Tekanan darah diukur dengan menggunakan Sphgymomanometer yang dibalutkan pada lengan kiri atas sampel, dibantu dengan stetoskop untuk mendengarkan suara denyut jantung kira-kira diatas daerah fossa cubiti (cekungan) pada pergelangan tangan kiri atas.

\section{Analisis data penelitian}

Analisis data penelitian dianalisis dengan menggunakan uji-t (beda) dengan taraf signifikasi $5 \%$. Uji-t menghasilkan nilai t hitung dan nilai probabilitas $(p)$ yang dapat digunakan untuk membuktikan hipotesis ada atau tidak adanya pengaruh secara signifikan. Cara menentukan signifikan tidaknya adalah jika nilai $p<0,05$ maka ada perbedaan signifikan, selanjutnya jika $p>0,05$ maka tidak ada perbedaan signifikan. 
HASIL

Tabel 1. Deskripsi Data Pretest

\begin{tabular}{cccccc}
\hline Deskripsi & Kelompok & Mean & SD & Minimum & Maximum \\
\hline \multirow{2}{*}{ Pre-test Sistole } & Eksperimen & 116.52 & 9.58 & 100 & 131 \\
& Kontrol & 116.51 & 7.76 & 111 & 131 \\
\hline \multirow{2}{*}{ Pre-test Diastole } & Eksperimen & 72.87 & 8.35 & 61 & 81 \\
& Kontrol & 74.76 & 7.18 & 61 & 92 \\
\hline \multirow{2}{*}{ Pre-test Denyut Nadi } & Eksperimen & 76.88 & 9.98 & 62 & 93 \\
& Kontrol & 79.88 & 7.24 & 63 & 94 \\
\hline
\end{tabular}

Tabel 2. Deskripsi Data Postest

\begin{tabular}{cccccc}
\hline Deskripsi & Kelompok & Mean & SD & Minimum & Maximum \\
\hline \multirow{2}{*}{ Post-test Sistole } & Eksperimen & 118.35 & 9.27 & 112 & 141 \\
& Kontrol & 132.23 & 6.18 & 121 & 140 \\
\hline \multirow{2}{*}{ Post-test Diastole } & Eksperimen & 74.01 & 7.31 & 61 & 91 \\
& Kontrol & 84.61 & 7.26 & 71 & 101 \\
\hline Post-test Denyut & Eksperimen & 82.62 & 8.75 & 64 & 95 \\
Nadi & Kontrol & 105.02 & 10.37 & 85 & 121 \\
\hline
\end{tabular}

\section{Uji Normalitas}

Sebelum dianalisis dengan uji-t, terlebih dahulu dilakukan uji prasyarat, yaitu uji normalitas untuk mengetahui apakah sampel berasal dari populasi yang berdistribusi normal. Pengujian normalitas menggunakan ketentuan, apabila angka signifikansi (sig) dari tekanan darah dan denyut nadi baik pretest maupun posttest $>0,05$ normal.

Tabel 3. Angka Signifikansisi (sig) Denyut Nadi

\begin{tabular}{|c|c|c|c|c|c|c|c|}
\hline \multirow{2}{*}{ Data } & \multicolumn{3}{|c|}{ Pre-test } & \multirow{2}{*}{ Data } & \multicolumn{3}{|c|}{ Post-test } \\
\hline & Kelompok & Sig. & Ket. & & Kelompok & Sig. & Ket. \\
\hline \multirow{2}{*}{ Sistole } & Eksperimen & 0.438 & Normal & \multirow{2}{*}{ Sistole } & Eksperimen & 0.402 & Normal \\
\hline & Kontrol & 0.191 & Normal & & Kontrol & 0.062 & Normal \\
\hline \multirow{2}{*}{ Diastole } & Eksperimen & 0.185 & Normal & \multirow{2}{*}{ Diastole } & Eksperimen & 0.255 & Normal \\
\hline & Kontrol & 0.068 & Normal & & Kontrol & 0.138 & Normal \\
\hline \multirow{2}{*}{ DN } & Eksperimen & 0.962 & Normal & \multirow{2}{*}{ DN } & Eksperimen & 0.985 & Normal \\
\hline & Kontrol & 0.874 & Normal & & Kontrol & 0.865 & Normal \\
\hline
\end{tabular}

Angka signifikansi pretest dan posttest denyut nadi didapat lebih besar dari 0,05. Jadi sampel data sebelum dan sesudah perlakuan sport massage berdistribusi normal.

\section{Uji Homogenitas}

Uji homogenitas bertujuan untuk mengetahui apakah sampel berasal dari populasi yang memiliki sebaran homogen ataukah heterogen. Pengujian homogenitas menggunakan uji $\mathrm{F}$ dengan ketentuan apabila angka signifikansi (sig) $>0,05$ berarti homogen.

Tabel 4. Angka Signifikansisi (sig) Uji Homogenitas

\begin{tabular}{lccc}
\hline \multicolumn{1}{c}{ Pasangan Data } & F hitung & Sig. & Keterangan \\
\hline Pre-test Sistole Eksperimen - Pretest Sistole Kontrol & 0.874 & 0.355 & Homogen \\
Pre-test Diastole Eksperimen - Pretest Diastole Kontrol & 2.196 & 0.146 & Homogen \\
Pre-test DN Eksperimen - Pretest DN Kontrol & 0.738 & 0.396 & Homogen \\
Post-test Sistole Eksperimen - Posttest Sistole Kontrol & 0.002 & 0.998 & Homogen \\
Post-test Diastole Eksperimen - Posttest Diastole Kontrol & 2.038 & 0.164 & Homogen \\
Post-test DN Eksperimen - Posttest DN Kontrol & 1.082 & 0.308 & Homogen \\
\hline
\end{tabular}




\section{Uji Hipotesis}

Uji- $t$ digunakan untuk mengetahui ada tidaknya perbedaan tekanan darah dan denyut nadi pada kelompok eksperimen dan kontrol. Selanjutnya untuk mengetahui ada tidaknya perbedaan tekanan darah dan denyut nadi pada kedua kelompok tersebut, maka dilakukan uji-t. Hasil pengujian terangkum pada tabel berikut:

Tabel 5. Hasil Uji-t

\begin{tabular}{lccc}
\hline Pasangan Data & $\mathrm{t}$ & \multirow{2}{*}{ Sig. } & Ketrangan \\
\hline Pre-test Sistole Eksperimen - Pretest Sistole Kontrol & -0.649 & 0.521 & Tidak Signifikan \\
Pre-test Diastole Eksperimen - Pretest Diastole Kontrol & -0.681 & 0.501 & Tidak Signifikan \\
Pre-test DN Eksperimen - Pretest DN Kontrol & -0.973 & 0.339 & Tidak Signifikan \\
Post-test Sistole Eksperimen - Posttest Sistole Kontrol & -4.256 & 0.000 & Signifikan \\
Post-test Diastole Eksperimen - Posttest Diastole Kontrol & -4.374 & 0.000 & Signifikan \\
Post-test DN Eksperimen - Posttest DN Kontrol & -6.596 & 0.000 & Signifikan \\
\hline
\end{tabular}

Dari hasil uji-t diperoleh, Hipotesis nol (Ho) menyatakan tidak ada perbedaan pengaruh yang signifikan pada denyut nadi dan tekanan darah melalui pemberian sport massage. Hipotesis alternatif $(\mathrm{Ha})$ diperoleh bahwa ada perbedaan pengaruh yang signifikan pada denyut nadi dan tekanan darah melalui pemberian sport massage.

Dari penelitian ini diketahui bahwa nilai $p$ tekanan darah dan denyut nadi saat pretest lebih besar 0,05 . Maka data tekanan darah dan denyut nadi antar eksperimen dan kontrol saat pretest tidak signifikan. Selanjutnya, pada data posttest, nilai p tekanan darah dan denyut nadi saat pretest lebih besar dari 0,05 . Maka data tekanan darah dan denyut nadi antar eksperimen dan kontrol saat pretest tidak berbeda signifikan. Jadi, hipotesis yang menyatakan bahwa ada perbedaan pengaruh yang signifikan pada denyut nadi dan tekanan darah melalui pemberian sport massage, diterima.

\section{PEMBAHASAN}

Teknik yang baik bisa diperoleh dengan latihan yang terus menerus dan berkelanjutan menggunakan berbagai model latihan dan beban yang berbeda-beda. Akan tetapi, jika pemain atau atlit mengalami cedera maka akan sulit untuk memperoleh kemampuan gerakan teknik dasar yang baik. Sebagai contoh, pemain mengalami cedera kelelahan otot yang dikarenakan intensitas latihan tinggi. Sangat memungkinkan malah akan menghambat pemain berkembang (Kumairoh, 2014).

Teknik dasar dan ketrampilan gerakan merupakan faktor penting yang harus dimiliki oleh setiap pemain dalam upaya mencapai prestasi maksimal dalam permainan bola voli. Teknik dasar dan keterampilan gerakan dapat dilakukan secara sempurna apabila didukung dengan kemampuan motor fitnes yang maksimal. Seperti yang diungkapkan oleh (Hanafi, 2015) lewat penelitiannya untuk mengetahui peranan motor fitnes terhadap keterampilan bermain bola voli. Populasi penelitian ini, yaitu seluruh anggota club bola voli SMP Negeri 4 lhokseumawe. Sedangkan sampel yang diambil dari keseluruhan jumlah populasi berjumlah 20 orang. Pengumpulan data menggunakan tes motor fitnes dan tes ketrampilan bermain bola voli yang meliputi stradle chin, push up, vertical jump. Tes ketrampilan bolavoli meliputi servis, passing dan smash. Berdasarkan hasil perhitungan menunjukkan bahwa antara motor fitnes dengan ketrampilan bermain bola voli terdapat hubungan yang signifikan.

Berbagai bentuk latihan fisik yang dilakukan dengan menggunakan intensitas tinggi dapat menyebabkan peningkatan kadar asam laktat dalam otot maupun dalam darah. Seperti yang diungkapkan oleh (Nowo Tri Purnomo, 2015) dalam penelitiannya dengan tujuan untuk mengetahui pengaruh pemberian manipulasi massage tehnik sport massage terhadap perubahan kadar laktat darah setelah latihan anaerob. Penelitian yang telah dilakukan menunjukkan bahwa kadar laktat darah orang coba berkisar antara 1,6-2,3 $\mathrm{mMol} / \mathrm{l}$.Peningkatan kadar laktat tertinggi dan rerata kecepatan buang laktat tercepat setelah manipulasi massage sport massase membantu mempercepat pembuangan laktat dari otot ke darah lebih baik dan meningkatan kecepatan sirkulasi. Kondisi ini memungkinkan lebih cepat terjadinya penggunaan laktat sebagai 
sumber energy. Penimbunan laktat dalam darah menjadi masalah mendasar dalam kinerja fisik karena menimbulkan kelelahan dan menurunkan kinerja fisik. pemulihan laktat yang penting adalah meningkatkan aliran darah, meningkatkan cardiac output, meningkatkan transport laktat, sehingga cepat membentuk energi kembali. Laktat bisa hilang dengan istirahat, tetapi dengan manipulasi massage proses pengeluaran sisa-sisa pembakaran ke aliran darah dipercepat. Massage dapat membantu peningkatan aliran darah pada otot skelet sebagai jalan percepatan tingkat aliran laktat untuk dieliminasi keberbagai tempat, dengan demikian massage dapat digunakan sebagai teknik untuk mempercepat pembersihan laktat (Nowo Tri Purnomo, 2015).

Pemberian sport massage pada seluruh anggota tubuh maupun bagian tubuh tertentu akan meningkatkan sistem kerja tubuh. Salah satu contoh adalah pemberian sport massage secara general pada orang yang telah beraktivitas berat. Jumlah denyut nadi manusia dapat dipengaruhi oleh aktivitas fisik yang berat. Pada kondisi tubuh melakukan aktivitas fisik yang berat tersebut sistem saraf otonom terlibat. Pusat emosi di otak, yang disebut hipotalamus, mengirimkan tanda-tanda melalui saraf-saraf ke berbagai kelenjar endokrin dan organorgan bagian dalam tubuh. Hormon-hormon dikeluarkan dalam jumlah yang lebih besar dan lebih banyak pula gula yang dilepaskan. Selain itu, cabang-cabang tenggorokan memanjang dan pernapasan menjadi berat serta lebih cepat. Darah disuplai dalam jumlah yang besar untuk memenuhi kebutuhan sari makanan dan oksigen ke organ-organ yang penting yang telah digunakan untuk aktivitas fisik yang berat, dan denyut nadi pun bertambah cepat.

Penurunan denyut nadi juga dipengaruhi oleh sistem saraf otonom yang berpusat di batang otak, tulang belakang, dan hipotalamus. Sistem saraf otonom yang berperan adalah saraf parasimpatis yang berada di depan ruas-ruas tulang belakang dan berhubungan dengan tulang belakang melalui serabut saraf. Pada jantung saraf parasimpatis berperan menurunkan kecepatan denyut nadi, sedangkan saraf simpatis berperan sebaliknya.

Pada dasarnya, tubuh selalu berusaha dalam keadaan seimbang. Pemberian sport massage pada bagian tubuh, khususnya pada bagian yang terdapat otot besar, akan membantu tubuh untuk kembali dalam keadaan seimbang dan menyembuhkan dirinya sendiri. Pemberian sport massage akan memperlancar aliran darah, merilekskan otot, dan merangsang sistem kerja tubuh, sehingga ketegangan tubuh akan berkurang, kerja organ-organ akan kembali normal, dan suplai darah pun akan kembali normal. Keadaan ini akan menyebabkan denyut nadi akan menurun.

Tekanan darah pada manusia juga dapat dipengaruhi oleh bermacam-macam faktor dan penyebab. Diantaranya faktor yang tidak bisa dikendalikan dan faktor yang bisa dikendalikan. Untuk faktor yang tidak bisa dikendalikan; misalnya gen(keturunan) dan faktor usia. Biasanya untuk usia orang yang lebih tua atau lansia mayoritas tekanan darah tinggi. Namun, untuk tekanan darah manusia yang dalam keadaan normal rata-rata yaitu 120/80 $\mathrm{MmHg}$. Untuk faktor tekanan darah yang bisa dikendalikan dapat bervariasi dan bermacam-macam. Diantaranya posisi tubuh, kondisi pernafasan/emosi, makanan, minuman, olahraga, tekanan/psikis, dan tidur.

Disisi lain, pemulihan atau recovery tekanan darah dan denyut nadi akibat aktivitas fisik yang berat berpengaruh secara signifikan dengan pemberian sport massage. Dikarenakan sport massage membantu pengembalian darah dari perifer ke jantung sehingga cardiac out put terjadi peningkatan. Cardiac out put adalah banyak darah yang dipompa selama satu menit (hasil kali stroke volume dengan frekuensi denyut jantung selama satu menit).

Sesuai dengan penelitian yang relevan dari (IImi, 2018) dengan judul pengaruh manipulasi sport massage terhadap intensitas nyeri setelah aktivitas eksentrik hasil penelitian diketahui bahwa pemberian manipulasi sport massage pada kelompok perlakuan manipulasi effleurage, petrissage, shaking, tapotement dan kontrol 6 jam setelah aktivitas eksentrik dapat menurunkan intensitas nyeri $(2,17 \pm 0,753 ; 1,50 \pm 0,837 ; 2,20 \pm 0,837$ $; 1,40 \pm 0,548 ; 3,83 \pm 0,753$ ) dengan nilai $p=0,001$ pada jam ke 24 . Sport massage yang diberikan pada seluruh tubuh memungkinkan menurunnya tekanan darah, terutama sport massage yang diberikan dengan lembut. Jadi, Pemberian sport massage berpengaruh secara signifikan terhadap penurunan tekanan darah dan denyut nadi. 


\section{KESIMPULAN}

Berdasarkan analisis hasil penelitian dan pembahasan, sehingga dapat disimpulkan bahwa ada pengaruh yang signifikan pada denyut nadi dan tekanan darah melalui pemberian sport massage, baik tekanan darah sistole, diastole, maupun denyut nadi. Oleh karena itu, sport massage dapat mengembalikan tekanan darah dan denyut nadi seperti semula.

\section{DAFTAR PUSTAKA}

Boguszewski, D., Szkoda, S., Adamczyk, J. G., \& Białoszewski, D. (2014). Sports mass age therapy on the reduction of delayed onset muscle soreness of the quadriceps femoris. Human Movement, 15(4), 234 237. https://doi.org/10.1515/humo-2015-0017

Daulay, B., \& Daulay, S. S. (2018). Pengembangan Variasi Latihan Kombinasi Passing dan Smash dalam Bola Voli. Jurnal Pendidikan Teknologi Dan Kejuruan. https://doi.org/10.24114/jptk.v20i1.11040

Davis, H. L., Alabed, S., \& Chico, T. J. A. (2020). Effect of sports massage on performance and recovery: a systematic review and meta-analysis. BMJ Open Sport \& Exercise Medicine, 6(1), 608-614. https://doi.org/10.1136/bmjsem-2019-000614

Dawson, K. A., Dawson, L., Thomas, A., \& Tiidus, P. M. (2011). Effectiveness of regular proactive massage therapy for novice recreational runners. Physical Therapy in Sport, 12(4), 182-187. https://doi.org/10.1016/j.ptsp.2011.02.007

DiStefano, L. J., Distefano, M. J., Frank, B. S., Clark, M. A., \& Padua, D. A. (2013). Comparison of integrated and isolated training on performance measures and neuromuscular control. Journal of Strength and Conditioning Research. https://doi.org/10.1519/JSC.0b013e318280d40b

Fallis, A. . (2013). Sport \& Remedial Massage Therapy. In Journal of Chemical Information and Modeling. https://doi.org/10.1017/CBO9781107415324.004

Farber, K., \& Wieland, L. S. (2016). Massage for Low-back Pain. Explore. https://doi.org/10.1016/j.explore.2016.02.014

goleman, daniel; boyatzis, Richard; Mckee, A., \& Perdana. (2018). Sejarah Bola Voli Permainan. Journal of Chemical Information and Modeling. https://doi.org/10.1017/CBO9781107415324.004

Hanafi, S. (2015). Hubunganmotor Fitness dengan Keterampilan Bermain Bola Voli Fazlullah. Jurnal ILARA. https://doi.org/http://journal.um.ac.id/index.php/pendidikan-jasmani/article/download/7505/3425

IImi, M. A. (2018). Pengaruh Manipulasi Sport Massage Terhadap Intensitas Nyeri Setelah Aktivitas Eksentrik. Jurnal Biosains Pascasarjana. https://doi.org/10.20473/BSN.V20I2.Y2018.10669

Kargarfard, M., Lam, E. T. C., Shariat, A., Shaw, I., Shaw, B. S., \& Tamrin, S. B. M. (2016). Efficacy of massage on muscle soreness, perceived recovery, physiological restoration and physical performance in male bodybuilders. Journal of Sports Sciences, 34(10), 959-965. https://doi.org/10.1080/02640414.2015.1081264

Kristriawan, A., \& Sukadiyanto, S. (2016). Pengaruh metode latihan dan koordinasi terhadap smash backcourt atlet bola voli yunior putra. Jurnal Keolahragaan. https://doi.org/10.21831/jk.v4i2.10890

Kumairoh, S. (2014). Terhadap Kelelahan Otot Anaerob. Journal of Nutrition College Diponegoro University.

La'I, R. A., \& Haluti, A. (2018). Pelatihan Teknik Dasar Permainan Bola Voli. MONSU'ANI TANO: Jurnal Pengabdian Masyarakat. https://doi.org/10.32529/tano.v111.245

Nowo Tri Purnomo. (2015). Perubahan kadar laktat darah akibat manipulasi sport massage pada latihan anaerob. Jurnal IImiah Penjas, 1(2).

Paoli, A., Bianco, A., Battaglia, G., Bellafiore, M., Grainer, A., Marcolin, G., .. Palma, A. (2013). Sports massage with ozonised oil or non-ozonised oil: Comparative effects onrecovery parameters after maximal effort in cyclists. Physical Therapy in Sport. https://doi.org/10.1016/j.ptsp.2012.11.004

Peterson, A. R., Smoot, M. K., Erickson, J. L., Mathiasen, R. E., Kregel, K. C., \& Hall, M. (2015). Basic recovery 
aids: What's the evidence? Current Sports Medicine Reports. https://doi.org/10.1249/JSR.0000000000000159

Pranopik, M. R. (2017). Pengembangan Variasi Latihan Smash Bola Voli. JURNAL PRESTASI. https://doi.org/10.24114/jp.v1i1.6495

Raya, R. I., Yunus, M., \& Adi, S. (2019). Hubungan Intensitas Aktivitas Fisik dan Masa Kerja dengan Prevalensi dan Tingkatan Low Back Pain pada Pekerja Kuli Angkut Pasir. Sport Science and Health, 1(2), 102109. Retrieved from http://journal2.um.ac.id/index.php/jik/index

Samsudin, S., \& Rahman, H. A. (2016). Pengaruh metode pembelajaran drill, bermain, dan kelincahan terhadap kemampuan passing dalam permainan bola voli. Jurnal Keolahragaan. https://doi.org/10.21831/jk.v4i2.10899

Schilz, M., \& Leach, L. (2020). Knowledge and Perception of Athletes on Sport Massage Therapy (SMT). International Journal of Therapeutic Massage \& Bodywork.

Trampas, A., Mpeneka, A., Malliou, V., Godolias, G., \& Vlachakis, P. (2015). Immediate effects of CoreStability exercises and clinical massage on Dynamic-Balance performance of patients with chronic specific low back pain. Journal of Sport Rehabilitation. https://doi.org/10.1123/jsr.2014-0215 